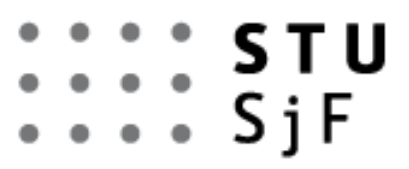

\section{Journal of MECHANICAL ENGINEERING - Strojnícky časopis}

VOLUME 66, NO 2, 2016

\author{
pp. $95-100$
}

DOI:10.1515/scjme-2016-0023

\title{
THE EFFECT OF LANDSLIDE ON GAS PIPELINE
}

\section{VALKOVIČ Vojtech ${ }^{\mathbf{1}}$, JANČO Roland ${ }^{\mathbf{2}}$, FRYDRÝŠEK Karel ${ }^{\mathbf{3}}$}

\author{
${ }^{1}$ Slovak University of Technology in Bratislava, Faculty of Mechanical Engineering, Institute of Applied \\ Mechanics and Mechatronics, Nám. slobody 17, 81231 Bratislava, Slovakia, e-mail: vojtech.valkovic@stuba.sk \\ ${ }^{2}$ Slovak University of Technology in Bratislava, Faculty of Mechanical Engineering, Institute of Applied \\ Mechanics and Mechatronics, Nám. slobody 17, 81231 Bratislava, Slovakia, e-mail: roland.janco@stuba.sk \\ ${ }^{3}$ VSB-Technical University of Ostrava, Faculty of Mechanical Engineering, Department of Applied Mechanics, \\ 17.listopadu 15, Ostrava, 17. listopadu 15/2127, 70833 Ostrava-Poruba, Czech Republic; email: \\ karel.frydrysek@vsb.cz
}

\begin{abstract}
The present paper deals with the calculation of stresses on the pipeline system embedded on a flexible substrate which is burdened by a landslide. As well as taking into account the probability of the influences acting on the pipe as wall thickness, and others.
\end{abstract}

KEYWORDS: Beam, elastic foundation, landslide, probability, SBRA Method, reliability assessment, Winkler model, Monte Carlo method, pipe excavation

\section{Introduction}

Generally, the analysis of bending of beams on an elastic foundation is developed on the assumption that the reaction forces of the foundation are proportional at every point to the deflection of the beam at that point. The vertical deformation characteristics of the foundation are defined by means of identical, independent, closely spaced, discrete and linearly elastic springs. The constant of proportionality of these springs is known as the modulus of subgrade reaction, ks. This simple and relatively crude mechanical representation of soil foundation was firstly introduced by Winkler, in 1867 . The Winkler model, which has been originally developed for the analysis of railroad tracks, is very simple but does not accurately represents the characteristics of many practical foundations. One of the most important deficiencies of the Winkler model is that a displacement discontinuity appears between the loaded and the unloaded part of the foundation surface. In reality, the soil surface does not show any discontinuity (Fig. 1) [1].
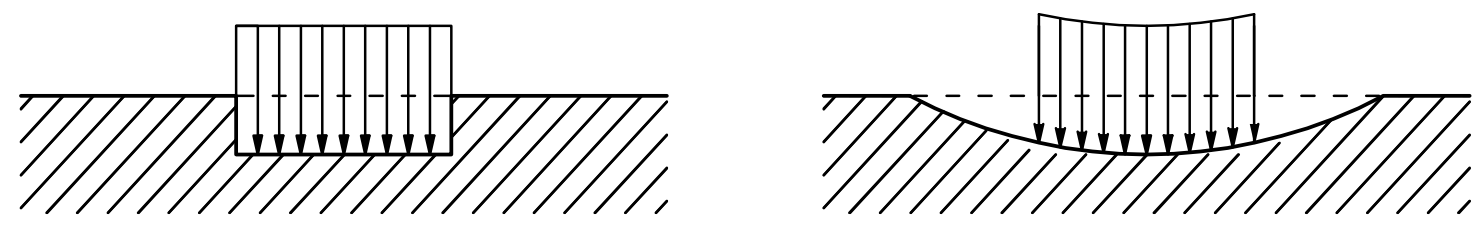

Fig. 1 Deflections of elastic foundations under uniform pressure $p$

(a) Winkler Foundation. (b) Elastic solid

The work is focused on the calculation of stress and safety pipe (beam) on a flexible substrate. Pipeline due to landslide slope change its deposit and thus the inside force effects. Such random change is unavoidable and should therefore be probabilistic evaluation to 
determine the status of its security. To deal with the stress pipes (tubes) in the edge of the landslide slope.

Investigate earth movement pattern, which result in a block movement of the slope of constant value towards stable $\Delta v$ part, the interface is defined by a single lateral cracks (Figure 2). Fold line pipe axis is shown by a solid line. Imagine oven gas, which is at the point of the block side edge of the landslide cut, these pipes will not drift with diffraction-loaded remain straight (dashed). To these tubes get into the same state of strain, which caused landslide in continuous oven, we must not act in place of the cut internal force effects which, by antisymmetry task force represents Fo and of a size that caused by soil compression was just $\Delta v / 2$ (Figure 2) [2].

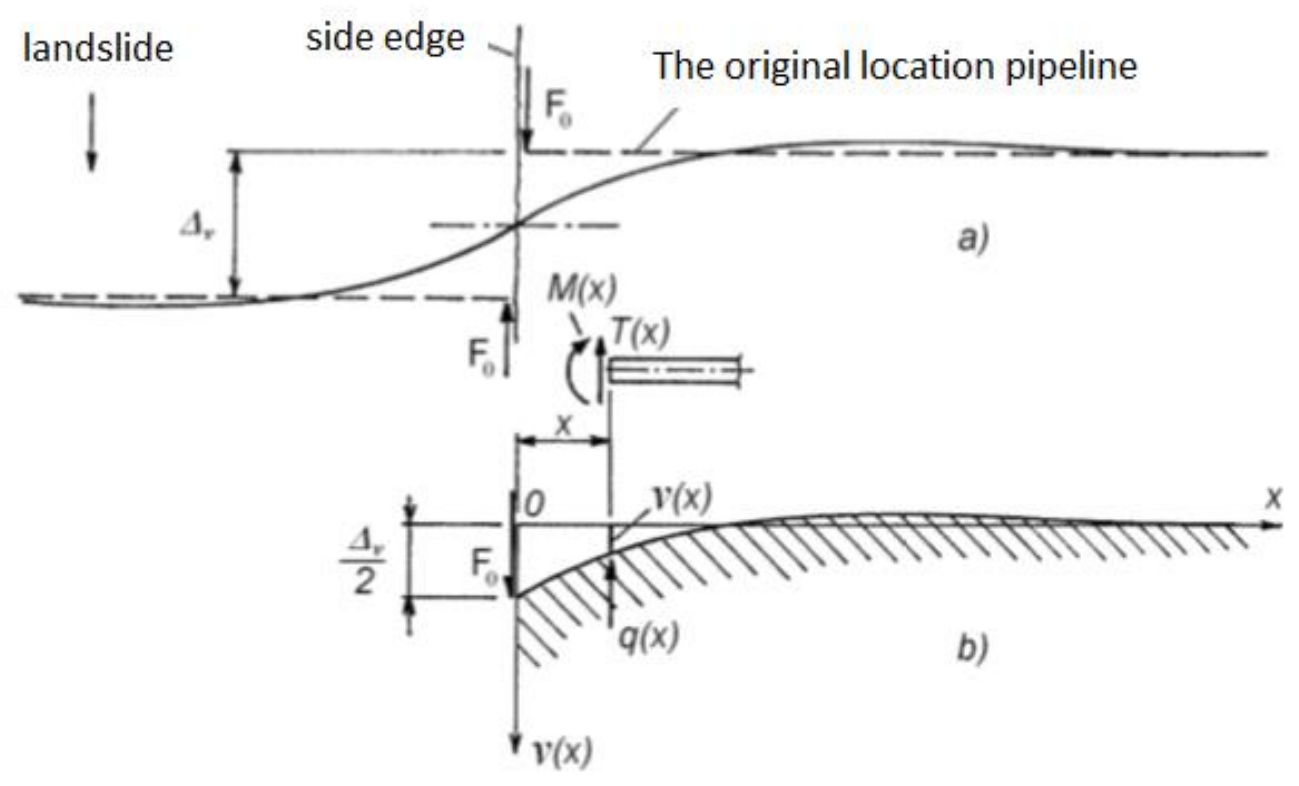

Fig. 2 Schematic pipes with landslides

Differential equation bending line beam on an elastic foundation is:

$$
E J_{z t} \frac{d^{4} v(x)}{d x^{4}}=q(x)=-k v(x)
$$

where $\mathrm{k}$ [N m-2] is the stiffness of the substrate is a continuous value of the load pipe, which corresponds to compression of the resilient unitary environment.

Differential Equations we seek in the form:

$$
v(x)=\left(A_{1} \cos \omega x+A_{2} \sin \omega x\right) e^{\omega x}+\left(A_{3} \cos \omega x+A_{4} \sin \omega x\right) e^{-\omega x},
$$

where $\mathrm{EJ}_{\mathrm{zt}}$ is the bending stiffness of the beam, and

$$
\omega=\sqrt[4]{\frac{k}{4 E J_{Z T}}}
$$

Since the infinite beam shows that the deformation in these locations is zero, it is clear that the constant $\mathrm{A}_{1}=\mathrm{A}_{2}=0$.

Corresponding stress in the general direction at the point $\mathrm{x}$ to the relationship: 


$$
\begin{gathered}
\operatorname{Mo}(x)=-E J_{Z T} v^{\prime \prime}(x)=-E J z t 2 \omega^{2}\left(-A_{4} \cos \omega x+A_{3} \sin \omega x\right) e^{-\omega x} \\
T(x)=-E J_{Z T} v^{\prime \prime \prime}(x)=-E J_{Z T} 2 \omega^{2}\left(\left(A_{3}+A_{4}\right) \cos \omega x-\left(A_{3}+A_{4}\right) \sin \omega x\right) e^{-\omega x}
\end{gathered}
$$

From the boundary conditions at the place edge beam we receive constants $A_{4}=0$ and $\mathrm{A}_{3}=\Delta v / 2$.

Bending line beam in the place landslide, with one lateral crack. We get the following equation $[2,4]$ :

$$
v(x)=\frac{\Delta v}{2} e^{-\omega x} \cos \omega x
$$

Corresponding to the maximum stress of the lateral bending moment forces respectively in the general location $\mathrm{X}$ are:

$$
\begin{aligned}
& \sigma_{\text {omax }}(x)=\frac{M_{O}(x)}{W_{O}} \\
& \tau_{\text {Tmax }}(x)=\frac{2 T(x)}{S}
\end{aligned}
$$

For our case it was necessary to determine the status of voltage deformation tubes for the value landslide $\Delta v=22.56 \mathrm{~cm}$, and the mean diameter of the pipe $\mathrm{d}=1200 \mathrm{~mm}$ with pipe wall thickness $\mathrm{h}=17 \mathrm{~mm}$, the value of the module to the base $\mathrm{k}=960 \mathrm{Ncm}^{-2}$. We expect modulus of elasticity $\mathrm{E}=2.1 \times 10^{5} \mathrm{MPa}$.

Software is used to calculate the Anthill, operated by Monte Carlo method.

To calculate the probability of the above example it is clear that, in practice, we can't consider the deterministic value to describe the actual state. Therefore, the input values are commissioned from a certain probability. $\Delta v$ for the value we defined probability function (Fig. 3) in order to best describe the state of shift that can occur on the beam [3-8].

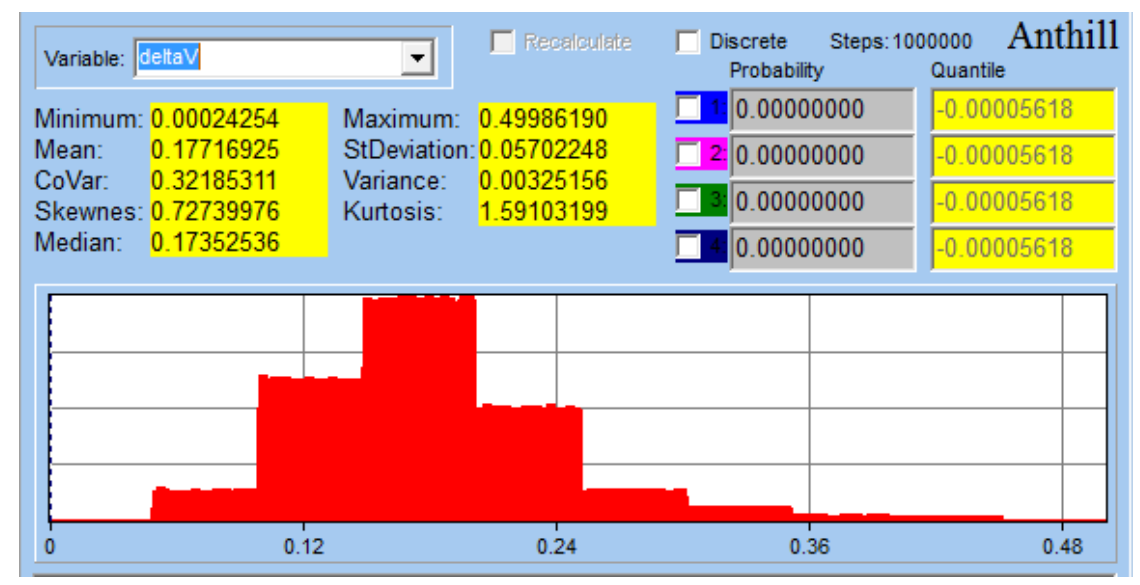

Fig. 3 Input values $\Delta v$

When entering constants in the calculation, we considered that each value has its variance. Young module $\mathrm{E}$, the stiffness of the substrate, the mean wall thickness $d$ and wall thickness $h$ is seen in the Table 1. 
Table 1 Input value

\begin{tabular}{|c|c|c|c|c|}
\hline & Maximum & Minimum & Mean & Median \\
\hline $\mathbf{E}[\mathrm{Pa}]$ & $2.288 \mathrm{e} 11$ & $1.872 \mathrm{e} 11$ & $2.0801 \mathrm{e} 11$ & $2.0804 \mathrm{e} 11$ \\
\hline $\mathbf{K}\left[\mathbf{N m}^{-2} \mathrm{~Pa}\right]$ & $9.984 \mathrm{e} 6$ & $9.216 \mathrm{e} 6$ & $9.5996 \mathrm{e} 6$ & $9.5990 \mathrm{e} 11$ \\
\hline $\mathbf{d s}[\mathrm{m}]$ & 1.248 & 1.152 & 1.999 & 1.200 \\
\hline $\mathbf{h}[\mathrm{m}]$ & 0.01768 & 0.01632 & 0.017 & 0.017 \\
\hline
\end{tabular}

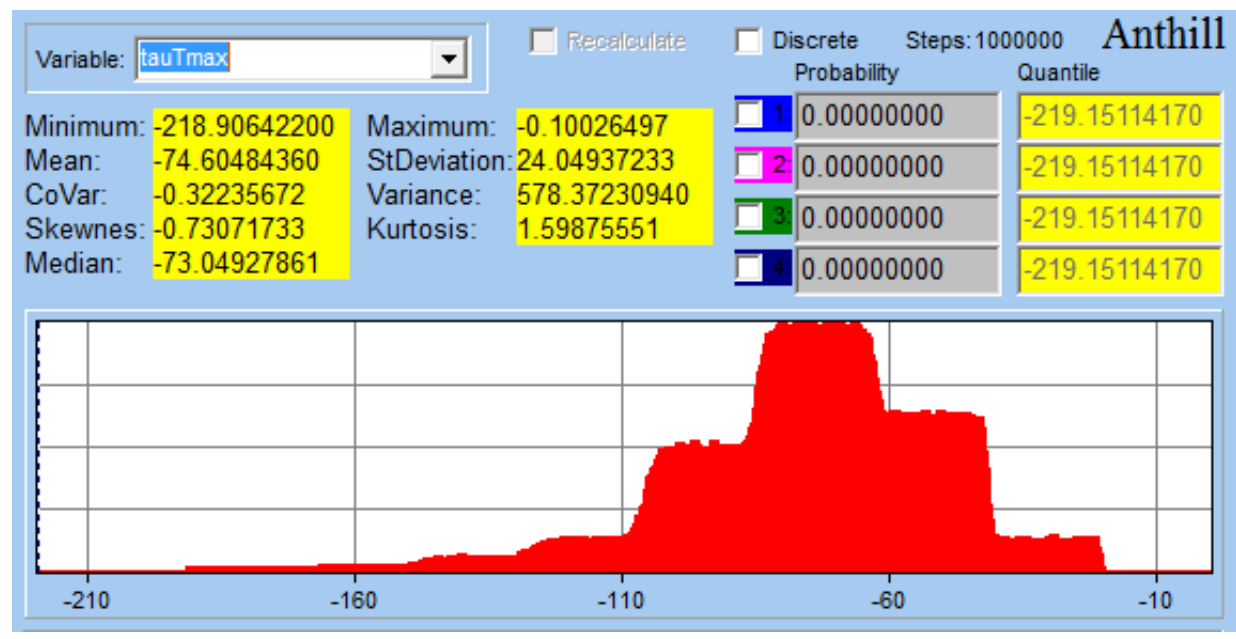

Fig. 4 Maximum shear stress value

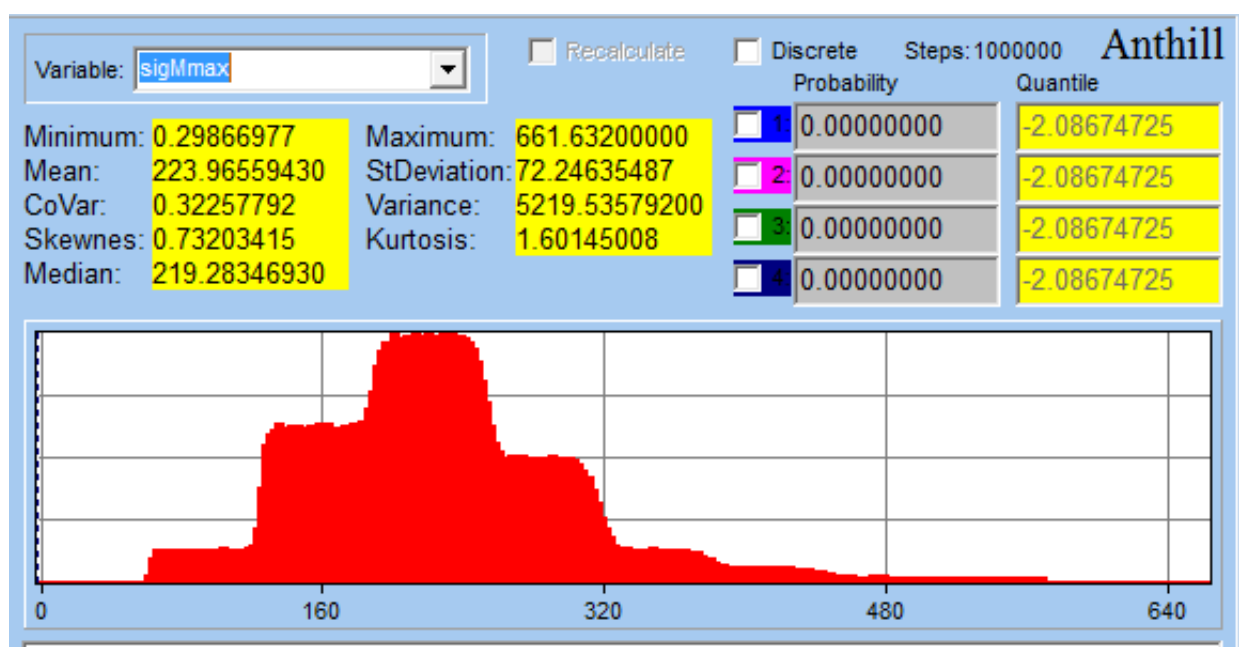

Fig. 5 Maximum stress value 


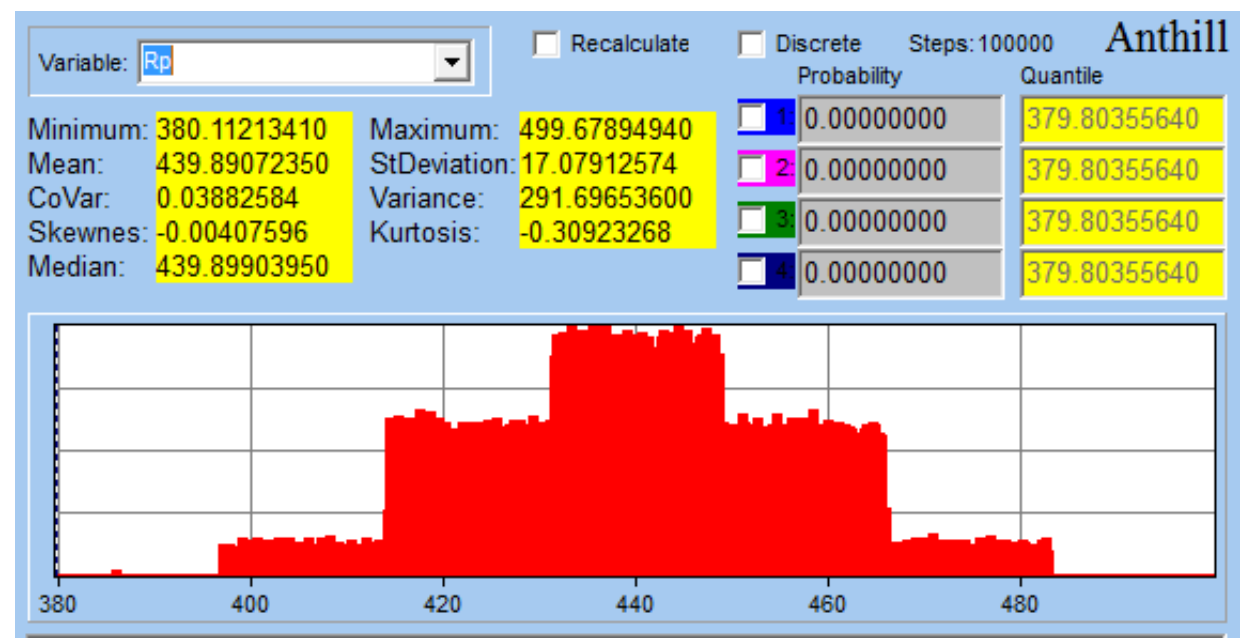

Fig. 6 Specified yield strength values

If we think of steel whose yield strength Rp vary within certain limits, we can write the probability function in the form of $\mathrm{RF}=\mathrm{Rp}$-sigMmax resulting in:

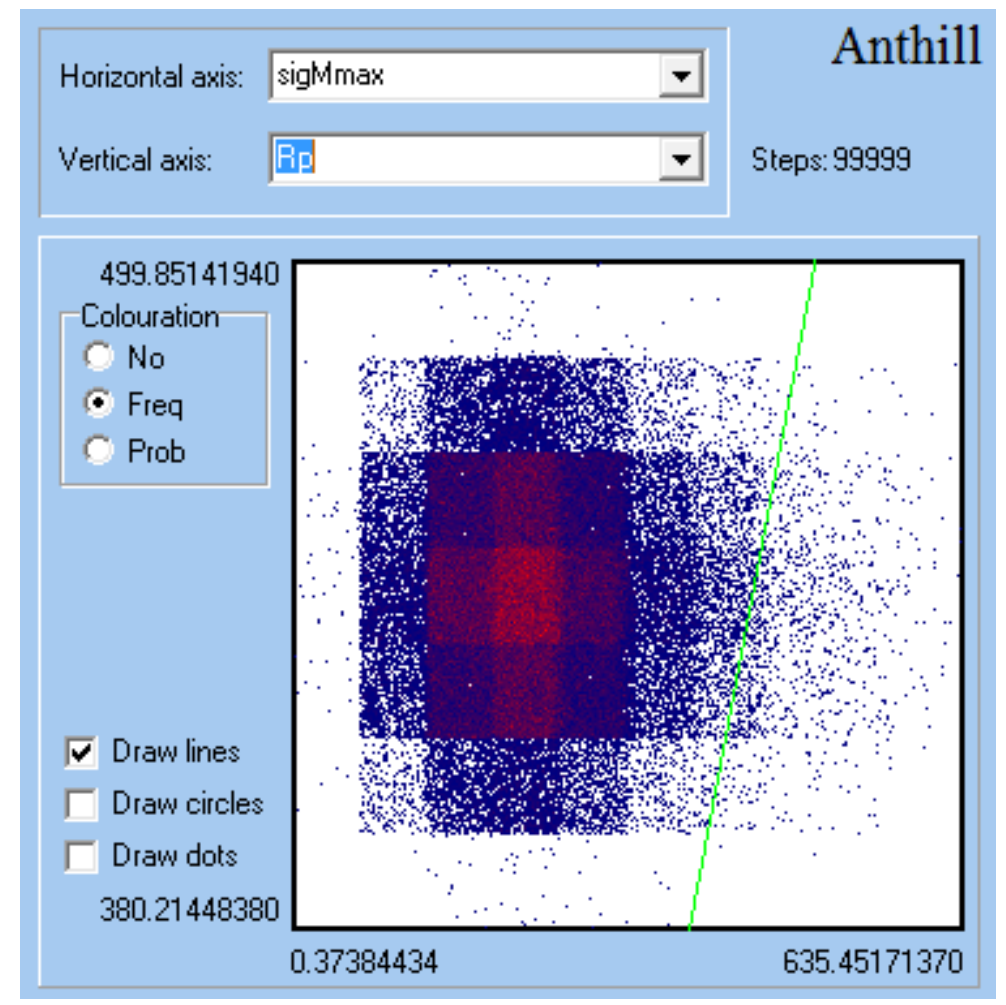

Fig. 8 Evaluation of the results

\section{CONCLUSION}

For practical calculation examples, it is clear that we can't rely on a deterministic approach, given that all the input parameters have their variations, causing significant changes in the output parameters (voltage, and the deflection.). In case of landslide model with one lateral cracks (see. Figure 2) which we calculate using the anthill we came values Table 2, the probabilistic approach differs significantly from deterministic, when taking into account random changes of input parameters.

As can be seen when comparing deterministic and probabilistic approach, the maximum values differ significantly (Table 2 ). 
Table 2 Comparison of deterministic and probabilistic approaches

\begin{tabular}{|l|c|c|c|c|}
\hline \multirow{2}{*}{} & \multirow{2}{*}{$\begin{array}{c}\text { Deterministic } \\
\text { approach }\end{array}$} & \multicolumn{3}{|c|}{ Probabilistic approach } \\
\cline { 3 - 5 } & & Max. value & Mean & \multicolumn{2}{|c|}{ Media } \\
\hline $\begin{array}{l}\tau \max \\
{[\mathrm{MPa}]}\end{array}$ & 95 & 218 & 74 & 73 \\
\hline$\sigma[\mathrm{MPa}]$ & 288 & 661 & 223 & 216 \\
\hline
\end{tabular}

From probability calculations we can say that the probability of failure on the pipeline for our case is $\mathrm{Pf}=1.019 \%$.

\section{Acknowledgements}

The article was supported by the STU Grant scheme for Support of Young Researchers and VŠB in Ostrava.

\section{REFERENCES}

[1] Frydrýšek, K.: Nosníky a rámy na pružném podkladu 1, VŠB - Technická univerzita Ostrava, 2006

[2] Frydrýšek, K., JANČO, R.: Nosníky a rámy na pružném podkladu 2, VŠB - Technická univerzita Ostrava, 2008

[3] FRYDRÝŠEK, K.: Pravděpodobnostní výpočty $\mathrm{v}$ mechanice 1 (Probabilistic Calculations in Mechanics 1). Department of Mechanics of Materials, Faculty of Mechanical Engineering, VSB - Technical University of Ostrava, ISBN 978-802482314-0, Ostrava, Czech Republic, 2010, pp.149.

[4] Musil, M.: Pasívna a aktívna vibroizolácia strojov. 1. vyd. Bratislava : Nakladatel'stvo STU, 2012. 152 s. ISBN 978-80-227-3733-3.

[5] Musil, M.: Základy dynamiky strojov s Matlabom. 1. vyd. Bratislava : Nakladatel'stvo STU, 2013.98 s., ISBN 978-80-227-3938-2.

[6] Jančo, R., Écsi, L., Élesztős, P.: FSW Numerical Simulation of Aluminium Plates by Sysweld - Part 1. In Strojnicky časopis - Journal of Mechanical Engineering, Vol. 66, Issue 1, Pages 47-52, ISSN 2450-5471

[7] Musil, M.: Localization and quantification of breathing crack. In Journal of Dynamic Systems Measurement and Control-Transactions of the ASME, Vol. 128, No. 2 (2006), pp. 458-462. ISSN 0022-0434.

[8] Sivý, M., Musil, M.: Procedure for Seismic Analysis of Liquid Storage Tanks using FEM Approach and Analytical Models. In: Advances in Mechanism Design II: Proceedings of the XII International Conference on the Theory of Machines and Mechanisms. Liberec: Springer, 2017, pp. 405. ISBN 978-3-319-44086-6. ISSN 22110984. 